\title{
Using Personal Portable Devices as Learning Tools in the English Class
}

\author{
El uso de dispositivos portátiles en la clase de inglés para \\ favorecer la producción del idioma*
}

Luz Edith Herrera Díaz

ehd63@hotmail.com

\begin{abstract}
María de los Milagros Cruz Ramos
tutor.milycruz@gmail.com
\end{abstract}

\author{
Mario Alberto Sandoval Sánchez \\ c.sandoval35@gmail.com \\ Universidad Veracruzana, Mexico
}

\begin{abstract}
A group of university students used a variety of personal portable devices (cellphones, tablets, laptops, and netbooks) which distracted them in English class. This qualitative action research aimed to implement activities entailing the use of such devices and to learn their impact on students' learning and the use of English in class. Thus, a series of applications was used to promote the use of these devices for the benefit of the English as a Foreign Language class. These applications included a learning management system that resembled a social network, a live interaction application, and an online dictionary. It was found that students were able to productively use these devices as learning tools plus they expressed comfort and interest in using them.
\end{abstract}

Key words: Action research, applications, distractor, learning tools, personal portable devices

Un grupo de 40 estudiantes universitarios usaban varios dispositivos personales portátiles (teléfonos celulares, tabletas, laptops) que los distraían en la clase de inglés. Esta investigación acción, de corte cualitativo, tuvo como objetivo implementar actividades que implicaron el uso de tales dispositivos y co-

* Received: January 13, 2014. Accepted: May 22, 2014.

How to cite this article (APA $6^{\text {th }}$ ed.):

Herrera Díaz, L. E., Cruz Ramos, M., \& Sandoval Sánchez, M. A. (2014). Using personal portable devices as learning tools in the English class. HOW, A Colombian Journal for Teachers of English, 21(2), 74-93. 
nocer su impacto en el aprendizaje y el uso que hacían del inglés los estudiantes en la clase. Se utilizaron una serie de aplicaciones fueron utilizadas para promover el uso de estos dispositivos en beneficio de la clase de inglés. Estas aplicaciones incluían un sistema de gestión del aprendizaje semejante a una red social, una aplicación de interacción en vivo y un diccionario en línea. Se encontró que los estudiantes usaron dichos dispositivos productivamente como herramientas de aprendizaje y expresaron comodidad e interés en usarlas así.

Palabras clave: aplicaciones, dispositivos portátiles personales, distractor, herramientas de aprendizaje, investigación acción

\section{Introduction}

This paper presents a description of the action research project "Using personal portable devices as learning tools in the English class," and its consequent educational intervention in two groups (first and fourth levels) at a private university in Mexico. After having taught and observed our own classes for two semesters, we identified that due to the fact that school policies have become either ambiguous or indifferent regarding portable device use in class, students show little care for those rules. Thus, they seem to condone taking out their cellphones, laptops, and tablets in the middle of a class to text their friends, or even to update their Facebook status, distracting them from the class activities.

This project arose from the conflict caused by the constant use of cellphones, tablets, and Wi-Fi accessibility at Universidad del Valle de México (UVM) - Veracruz campus, where, as we mentioned before, there is a lack of policies to regulate their use on the university's campus. A series of interviews of some of our coworkers validated our considering the importance and relevance of carrying out this research and trying to answer the following research questions: How can personal portable devices be used efficiently and constructively while students are doing innovative class activities according to the English language program for UVM?, and, How does this usage impact students' learning and their using English in class?

The aforementioned interviews also confirmed two things: that teachers shared a negative perception of portable device use in class and that students used devices such as cellphones, iPads, and laptops even when instructed not to do so. We also perceived a lack of institutional support, since there were no regulations regarding the use of this kind of devices. Then, we figured that even when any private institution may have guidelines for the use of portable devices, it could be counter-productive because private institutions tend to demonstrate constant innovation with technology as a way to relate to their target audience.

Working in a private institution where students are used to having the latest technology has made the presence of portable devices inevitable. That is, devices are always present in the classroom. More traditional teachers seemed to think the solution simply lay in collecting the 
portable devices at the beginning of class, but, as was mentioned before, times have changed and everything seems to indicate that using technology in class will only increase in years to come.

At the beginning of this project it was observed that students at UVM texted, tweeted, and even took photos during class; unfortunately, they did so only as a fun activity. Chatting with the person next to them does not necessarily distract students anymore. Nowadays, they can interact with people across the room, across campus, even in another school, city, or country; all of this via social networks and email.

The UNESCO (2012) has launched a series of papers that analyzes existing initiatives to use mobile learning in favor of education. According to their statistics, by 2012 there were over 5.9 billion mobile phone subscriptions worldwide, and for every person who accesses the Internet from a computer, two do so from a mobile device. Thus, we consider it important to understand how and when these devices could really function as an aid to learning.

In this context, we aimed to implement some innovative activities entailing the use of personal portable devices and also research the impact of such intervention on the students' learning and use of English in class. A number of activities were designed with the sole purpose of fostering a culture on portable devices use in which they were no longer perceived as distractions but welcomed in the classroom and used as learning tools. The activities implemented included the use of free software applications to reinforce the learning process while adding new tools as teaching aids.

We consider that the inclusion of some portable devices in class could consist of using them to carry out activities that support the learning, reinforcement, and/or practice of any aspect (written, verbal) of the target language. For example, these activities could include the use of online dictionaries to enrich and improve vocabulary uses and the use of audio recordings for conversation modeling and production, among others. It would also be considered as productive if students used their portable devices to communicate in English, especially if the communicative act involves real use of the language, such as expressing opinions and sharing experiences.

\section{Theoretical Framework}

\section{Use of Personal Portable Devices for Educational Purposes}

Mobile device is the term used to name information and communication technology (ICT) gadgets that contain fragile electronic components, need power to operate and connectivity for access (Goundar, 2011). According to Naismith, Lonsdale, Vavoula, and Sharples (2004), 
devices that can be classified as both portable and personal are what people most commonly think of in relation to mobile technologies: mobile phones, tablets, and laptops. Although these are defined as personal portable technologies, they are commonly thought of as mobile devices.

A number of experts (Ally, 2009; Valk, Rashid, \& Elder, 2010) have examined the extent to which the use of mobile devices can help support teaching and learning. They have concluded that there is evidence that mobile devices impact educational outcomes even if less evidence exists as to how they impact the outcomes. There have typically been some concerns about mobile devices in the classroom due to the belief that they can distract learners from work (McCoy, 2013). However, evidence seems to show the benefits outweigh this risk.

For instance, Jones (as cited in Lauricella \& Kay, 2010) found that a majority of college students own computers and wireless devices and believe that connectivity has enhanced their learning experience. Likewise, tablets were found to offer a beneficial addition to instruction in a study implemented in Australia. The report, produced by the State of New South Wales, Department of Education and Communities (2012), states that "all teachers involved reported that students' engagement and motivation had increased exponentially throughout the trial period. It was postulated that the increase in motivation had prompted the increase in student engagement" (p. 48).

There is some research regarding the use of mobile technologies to enhance English learning, however, there seems to be a lack of research regarding our particular local and national context. The UNESCO's report on mobile learning (2012) acknowledged the existence of 21 mobile learning initiatives in Latin America related to pedagogy in- and outside the classroom. Even when three of these initiatives took place in Mexico, none of them focused on language learning.

Going even further in the matter, Negrete (2010) points out that only 3\% of the educational intervention projects that take place in Mexico every year are carried out within the private sector (See Figure 1).

The former means there is little precedent regarding the incorporation of mobile devices into the English language teaching-learning process within our national private educational system. Furthermore, it seems that this thematic concern had never been addressed before at UVM - Veracruz campus - even when teachers have shown a generalized feeling of discomfort towards students' use of mobile technology in the classroom.

\section{Innovation and Educational Interventions}

Educational interventions have been defined as efforts to implement and improve educational programs within a specific context, and are based on research. Barraza (2006) 


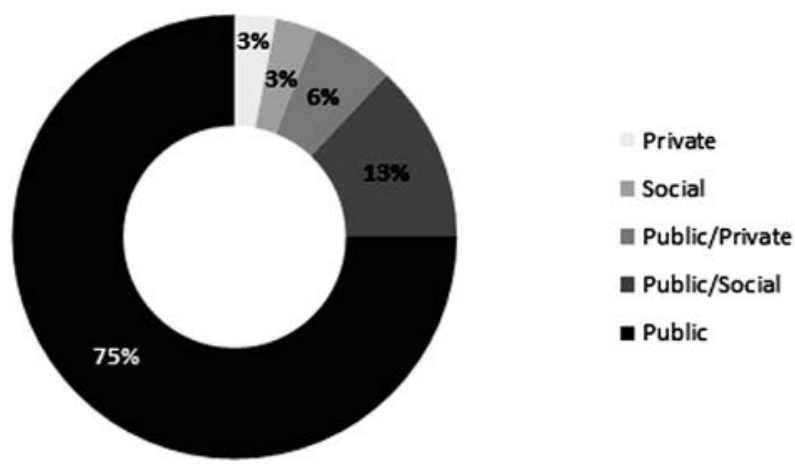

Figure 1. Educational Intervention Projects in Mexico (Negrete, 2010)

explains that educational interventions seek innovative approaches to problematic concerns. He adds that innovation emerges from an individual concern, or experiences, which acquire a particular meaning from the professional practice of the people involved.

Based on this perspective, it is possible to place teachers at the center of problematic situations as the main agents of change. Thereby, teachers also become researchers and are responsible for identifying problematic situations, aspects that need to be fixed or that could be improved.

According to Barraza (2005), there are three different kinds of educational innovation. The main difference among these three lies in the specific area of the context being impacted by the changes produced as a result of the innovation and therefore the intervention. These areas can be the institution, the curriculum, or the teaching practice. The extent to which the changes are beneficial (or not beneficial) is determined by the teacher's own perceptions.

Hannan and Silver (2000) refer to innovation as a short-term strategy for maximizing profit or overcoming an immediate crisis. For Rogers (1995), "an innovation is an idea, practice, or object that is perceived as new by an individual or other unit of adoption" (p. 11, emphasis on the original). According to him, innovations are characterized by the following:

- their relative advantage (is it better than the idea it supersedes?)

- their compatibility (is it consistent with the existing values, past experiences or potential adopters' needs?)

- their complexity (is it difficult to understand and use?)

- their trialability (is it experimented with on a limited basis?) and 
- their observability (are the results visible to others?).

In a similar vein, Sikes (1992) asserts that talking about innovation in education is to talk about changes that are put into operation in the system and for it to develop at the same level that societies in the world do. Innovation in higher education can mean "a planned or deliberate process of introducing change, directed towards (but not necessarily achieving) improvements or solving or alleviating some perceived problem" (Hannan \& Silver, 2000, p. 10). In that sense, action research and consequently an educational intervention can be a vehicle for change, but it should be taken into consideration that innovation at this level is rather simpler than innovation at the operational level (Trebbi, 2003); to plan is not the same as to implement. In this particular case, we endeavored to implement an innovation (using cellphones, tablets and/or laptops for educational purposes in the English class) and observe its impact on the students' learning and use of this foreign language.

According to Brooks-Young (2010), teachers need to rethink their approach to instruction by trying out student-centered strategies and activities that focus on collaboration, communication, and problem solving. Touchstone (Cambridge University Press), which is the textbook used at the UVM, translated this idea into communicative language teaching (CLT) activities that focused on real language use. According to Richards (2006), CLT sets as its goal the teaching of communicative competence, which is opposed to grammatical competence. The former focuses on providing learners with the skills necessary to engage in meaningful conversation, whereas the latter focuses on building sentences and knowing how sentences must be formed.

As we have previously defined, the educational intervention is understood as the set of actions, pedagogical and methodological assessment, which are developed by the interventionists, whether institutionally or personally, to carry out a program previously designed, and aims for the people or group involved to reach the proposed objectives of the program (Jordán Padrón, Pachón González, Blanco Pereira, \& Achiong Alemañy, 2011). It is important to mention that, since we had to follow a program, this project was a complement to the class curriculum. Thus, it was possible to include the use of cell phones, tablets and/or laptops as part of the teaching-learning process without altering the program previously set.

\section{Methodology}

\section{Methodological Approach}

The present project, relevant to the educational milieu, was carried out under the umbrella of qualitative research, and specifically developed through action research, considering it as a way of studying and exploring a social situation with the purpose of improving it (Suárez 
Pazos, 2002). In the educational field, Chamot, Barnhardt and Dirstine (1998) consider that the basis of action research is the classroom, and is carried out by teachers intending to reflect on and improve their own teaching practice.

According to Burns (2010), "action research involves taking a self-reflective, critical, and systematic approach to exploring your own teaching contexts" (p. 2). Later in the process, teacher-researchers need to work on the construction of proposals that help improve or change their context, which can be as particular as the teacher's own practice or as general as the institution where the experience takes place.

In view of the above, Kemmis and McTaggart (1988) state that action research normally involves four broad phases in a cycle of research: planning, action, observation, and reflection. In the first one, the teacher-researcher identifies a problem or issue and, in order to solve or improve it, s/he develops a plan of action. In the second one, the plan is implemented, that is, there is a deliberate intervention in the class (See Innovation and Educational Intervention in the Theoretical Framework section above). In the third one, the teacher-researcher systematically observes and documents the effects of the intervention; that is, at this point, the collection of data takes place. In the last phase, the teacher-researcher reflects on, evaluates, describes such effects, and intends to understand the issue in question, which may lead to carrying out further cycles. In other words, in the fourth phase, the data analysis is carried out.

Planning phase: Selection of sample and design of activities. The activities in this project were planned to provide an interesting twist on classwork, especially on quizzes. In this respect, Brooks-Young (2010) also suggests that educators need to adapt their approach to instruction continuously in order to ensure that classroom activities remain relevant. Based on this knowledge, an important aspect in designing the activities for the intervention was to include different group dynamics so that collaboration and more natural communication could take place.

Once we had identified the issue to be improved and had planned the activities aiming to do so, we selected the students who would participate in the study.

Participants. After identifying the problem related to the use of portable devices in our English classes at UVM, as previously explained, it was decided that the intervention activities were to take place in two different groups, each led by a different teacher-researcher. These groups were at opposite ends of the spectrum in the English program of this university. Group A was a Level 4 class in which students were already fluent in the language, whereas Group B was a Level 1 class composed of true beginners.

There were 24 students in Group A, which consisted of students with majors like architecture, communication, and engineering. Their level of English was intermediate. There were 18 students in Group B, who belonged to three different majors: gastronomy, tourism and 
industrial engineering. Fifteen out of the 18 were true beginners who showed little confidence from the first day of classes. In both groups, the students' ages ranged from 17 to 24 .

Action Phase: Intervention (implementation of activities). A total of five core activities (See Table 1) were designed to be implemented using topics and materials relevant to the course content of each of the two groups. The activities were implemented on a weekly basis with the purpose of molding routines and habits regarding the students' use of cell phones, tablets, and laptops. This implementation would ultimately impact the teacher-researchers' practice too. Before the actual implementation started, a week was assigned to help students get acquainted with the tools they needed to use on their portable devices. This was called an induction week, and it made the transition smooth and practically effortless.

The activities were to be implemented over a period of eight weeks. As has been mentioned, the induction week was dedicated to helping students get familiar with the tools to be used, and the next seven weeks to the actual implementation of the innovative activities. However, this could not be done on the date originally set, since a series of problems arose during the week the implementation was supposed to begin.

Wi-Fi connection was lost for about three weeks due to constant rains, so, Group B's acquaintance process began at the language lab. The activities carried out involved working with all of the tools described in the following section. It is important to mention that the innovative activities also matched the learning objectives the students were to achieve, according to the textbook units being covered in those seven weeks.

Before describing the activities implemented, it is important to describe the tools selected for such implementation. All of the tools listed below are free of charge and can be accessed from all kinds of portable devices, such as cellphones, iPods, tablets (iPads), and laptops. With the purpose of acquainting the reader with their possible uses, we describe here each of the sites and applications we have referred to as tools until now.

\section{Sites and applications used for the intervention}

(a) Merriam-Webster Dictionary:

- Merriam-Webster online dictionary: Free online dictionary, thesaurus, Spanish-English and medical dictionaries, audio pronunciations, word of the day, word games, and many more high-quality features (accessed from http://www.merriam-webster.com/ on laptops and tablets, accessed from i.word.com on other smartphones).

- Merriam-Webster App: In addition to all the definitions from Merriam-Webster's Collegiate Dictionary, this app offers voice search, synonyms, antonyms, example sentences, word of the day, and more. 
(b) Socrative: According to the product's own website, ${ }^{1}$ Socrative is a smart student response system that empowers teachers to engage their classrooms through a series of educational exercises and games via smartphones, laptops, and tablets. Teachers need to create an account, which will provide them with a "room" number. Students need to be provided with this number to access a private group where they will be able to interact posting anonymous opinions and comments. They can also take part in games and competitions where they have to be the ones to answer a question, or even answer a quiz previously created by the teacher. Unlike comments, quizzes will require students to introduce their names, letting teachers know the students' scores. One of the most attractive aspects of this web application is that it can send grade reports to the teacher's email account, which saves time commonly used in grading.

(c) Edmodo: It is a free, secure social network for classroom use. Edmodo can be accessed online or through a portable device. It can be considered an academic version of Facebook, since students and teachers are able to post and comment on each other's contributions. Edmodo allows teachers to share announcements and assignments for the class. It is also possible to add files and links to other websites for students to check. In education, Edmodo's biggest advantage over Facebook is its being a safe and secure virtual learning environment - with no apps, games, or advertisements included.

Observation phase: Data collection. Doing action research requires data collection methods such as journals, anecdotal records, field notes, audio and video recordings, photos, interviews, questionnaires, tests, document analysis, autobiographies, and so forth (Hopkins, 1989; Winter, 1989). These elements help us know, as much as possible, the situation and events taking place in the class under scrutiny. Therefore, during this intervention, namely, the second phase (action), which overlaps with the third phase (observation), both described by Kemmis and McTaggart (1988), a number of instruments for collecting data were used during the actual implementation of the activities planned as an innovative solution to the problem already identified.

Field notes, as well as the rest of the data collection instruments, were applied while supervising the implementation of the activities in both groups. The field notes presented are mainly descriptive, for they intend to detail events, activities, and particular actions of participants in the group, while also revealing how students reacted to the intervention. Photos were taken using portable devices such as cellphones and iPads. Photos helped

\footnotetext{
http://www.socrative.com/
} 
capture students' reactions as well as group dynamics. They were taken while students were engaged in different activities.

Screenshots, on the other hand, were taken to provide evidence of students' performance and improvement. Screenshots also show the different uses each of the resources served, whereas email notifications account for actual results students obtained in some of the activities. Furthermore, email notifications helped teachers and students keep up constant communication via social media. In the case of teachers, notifications informed them when students completed an activity or interacted with one another. In the case of students, notifications let them know the results they had obtained in a certain task, as well as teachers' and classmates' comments about their performance.

Table 1 shows the activities implemented and the methods used to collect the data during their implementation. It should be noted that since the groups were at different levels, the activities were the same but they were adapted according to each group's program.

Table 1. Activities Implemented and Methods to Collect Data

\begin{tabular}{|c|c|c|}
\hline Activity 1 & \multicolumn{2}{|c|}{$\begin{array}{l}\text { Setting up Edmodo and Socrative accounts: } \\
\text { Opening accounts and teaching students how to work on } \\
\text { Edmodo and Socrative }\end{array}$} \\
\hline Objective & $\begin{array}{l}\text { Get ready for the implementation } \\
\text { of the strategies and activities }\end{array}$ & Time: $25 \mathrm{~min}$ \\
\hline Description & \multicolumn{2}{|c|}{$\begin{array}{l}\text { Teacher explains how Edmodo works by projecting his/her } \\
\text { own "teacher" board to students and guiding them step by step } \\
\text { while they do the same on their personal portable devices. } \\
\text { Afterwards, teacher explains how to access a room on } \\
\text { Socrative. }\end{array}$} \\
\hline Resources & \multicolumn{2}{|l|}{ m.socrative.com, www.edmodo.com } \\
\hline $\begin{array}{l}\text { Data collection } \\
\text { method/tool }\end{array}$ & \multicolumn{2}{|c|}{ Edmodo screenshots, field notes, photos } \\
\hline Activity 2 & \multicolumn{2}{|c|}{$\begin{array}{l}\text { Looking up English definitions using Merriam-Webster: } \\
\text { Dictionary application/Online dictionary }\end{array}$} \\
\hline Objective & $\begin{array}{l}\text { Let students use their portable } \\
\text { devices to find definitions of new } \\
\text { vocabulary }\end{array}$ & $\begin{array}{l}\text { Time: As long as } \\
\text { necessary }\end{array}$ \\
\hline
\end{tabular}




\begin{tabular}{|c|c|c|}
\hline Description & \multicolumn{2}{|c|}{$\begin{array}{l}\text { When in class, students can freely search in their personal } \\
\text { portable devices without the assistance of the professor; this } \\
\text { can help the student to be more efficient and independent. }\end{array}$} \\
\hline Resources & \multicolumn{2}{|c|}{ Merriam-Webster App/Merriam-Webster online dictionary } \\
\hline $\begin{array}{l}\text { Data collection } \\
\text { method/tool }\end{array}$ & \multicolumn{2}{|l|}{ Photos of students' notebooks } \\
\hline Activity 3 & \multicolumn{2}{|c|}{$\begin{array}{l}\text { Answering questions, anonymously, in Socrative: } \\
\text { Sharing opinions on Socrative }\end{array}$} \\
\hline Objective & $\begin{array}{l}\text { Engage students in class } \\
\text { interaction via portable devices }\end{array}$ & Time: $15 \mathrm{~min}$ \\
\hline Description & \multicolumn{2}{|c|}{$\begin{array}{l}\text { Teacher will instruct students to access m.socrative.com and } \\
\text { provide them with his/her "room number." Once there, } \\
\text { teacher will orally ask them about something. Students will then } \\
\text { post their answers on Socrative to communicate and interact } \\
\text { with the rest of the class. }\end{array}$} \\
\hline Resources & \multicolumn{2}{|l|}{ m.socrative.com } \\
\hline $\begin{array}{l}\text { Data collection } \\
\operatorname{method/tool~}\end{array}$ & \multicolumn{2}{|c|}{ Photos, field notes, email notifications } \\
\hline Activity 4 & \multicolumn{2}{|l|}{$\begin{array}{l}\text { Taking quizzes in Edmodo: } \\
\text { Edmodo Quizzes }\end{array}$} \\
\hline Objective & $\begin{array}{l}\text { Evaluate students' progress } \\
\text { through quizzes }\end{array}$ & Time: $20 \mathrm{~min}$ \\
\hline Description & \multicolumn{2}{|c|}{$\begin{array}{l}\text { As in any social network, the teacher can post and attach files, } \\
\text { which in this case will be a quiz, so all students can see the } \\
\text { update and can start answering it. Students can also answer in a } \\
\text { Word document and attach it to the network's wall, or send it } \\
\text { to the teacher via private message on Edmodo. } \\
\text { A variation of this activity is having students solve quizzes } \\
\text { directly on Edmodo. The platform allows teachers to create } \\
\text { their own quizzes using different kinds of questions. Those } \\
\text { quizzes are visualized as apps. }\end{array}$} \\
\hline Resources & \multicolumn{2}{|l|}{ www.edmodo.com } \\
\hline $\begin{array}{l}\text { Data collection } \\
\text { method/tool }\end{array}$ & \multicolumn{2}{|c|}{ Quizzes' screenshots, grade logs' screenshots, field notes } \\
\hline
\end{tabular}




\begin{tabular}{|l|l|l|}
\hline Activity 5 & \multicolumn{2}{|l|}{$\begin{array}{l}\text { Submitting short paragraphs in Edmodo: } \\
\text { Edmodo written assignments }\end{array}$} \\
\hline Objective & $\begin{array}{l}\text { Get students to express their ideas } \\
\text { and/or opinions in writing }\end{array}$ & Time: 30 min \\
\hline Description & $\begin{array}{l}\text { Teacher posts instructions for the activities proposed by the } \\
\text { course book on Edmodo, or any other written task he/she } \\
\text { finds suitable. Students go to their Edmodo group's board } \\
\text { where they will read the instructions for the task to be } \\
\text { performed. Students write and edit their contributions which } \\
\text { will be checked by the teacher and possibly shared with the } \\
\text { class at teacher's discretion. }\end{array}$ \\
\hline Resources & www.edmodo.com \\
\hline $\begin{array}{l}\text { Data collection } \\
\text { method/tool }\end{array}$ & Field notes, screenshots, email notifications \\
\hline
\end{tabular}

Reflection phase: Data analysis. Having collected the data through the methods specified in Table 1, we proceeded to qualitatively analyze and synthesize them according to Burns' suggestions (2010). That is to say, we refined the wide view we had obtained by "coding [our] data into more specific patterns or categories" (Burns, 2010, p. 105). Therefore, in order to start processing the data, the field notes were coded as $\mathrm{FN}+$ date + group + subcategory; while the screenshots were coded as $\mathrm{SC}+$ date + group + subcategory, for example: FN11.10.12-A-socializing, or SC25.11.12-B-use English. It is worth mentioning that photos were not coded but selected according to their relevance in each category, once it had been identified. Moreover, following Stake (1998), who explains that while analyzing data you can sort records and transcripts and add frequencies to find patterns or meanings regarding your research, we detected coincidences and grouped them into several categories, after underlining, grouping, and summarizing (Maykut \& Morehouse, 1994; Patton, 2002; Robson, 2002). Then, these categories were outlined and grouped by making constant comparisons (Lincoln \& Guba, 1985; Maykut \& Morehouse, 1994), until we got the final two broad categories and their respective subcategories, as will be shown in the following section.

\section{Outcomes}

As we mentioned in the Observation Phase section, since both groups were in the same context and the only difference was the level, the activities implemented and the data collection methods were the same for both groups, thus, the data analysis was also carried out 
by using the same criteria. The interpretation of the categories and subcategories that emerged from the data analysis gave rise to two broad categories and their respective subcategories: (1) Students' Adopting a Constructive Usage of Personal Portable Devices as English Learning Tools and (2) Students' Learning and Usage of the Target Language (English) Through Personal Portable Devices. In order to support this action research's trustworthiness, which refers to the credibility of the findings of a certain research study (Lincoln \& Guba 1985; Maykut \& Morehouse 1994), we describe here the subcategories constituting the findings and present evidence from the data for each of these.

\section{Students' Adopting a Constructive Usage of Personal Portable Devices as English Learning Tools}

Use of the tools for socializing with classmates and teachers. Throughout the implementation of the diverse activities, we observed that the students adopted Edmodo as a new way to communicate in English with their peers as well as with the teacher-researchers. The friendly use of the language can be observed in Figure 2.

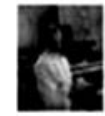

\section{Christopher F. to Me}

Hi teacher, good evening ... it's me Christopher, your best student... jejejeje I'm wating for the quizzes

greetings!!

17 hours ago | Reply | Share | Tag.

Figure 2. Screenshot From the Edmodo Platform

However, there was certain lack of homogeneity in the adoption of constructive portable device usage routines; also, even though most of the students showed great interest in working this way, were more engaged in class activities and in class work in general, and stopped texting so much in class, there were still a couple that continued engaging in the same diverting practices.

Figure 3 illustrates students' demeanor and immersion during class activities that were either individual or collaborative. 

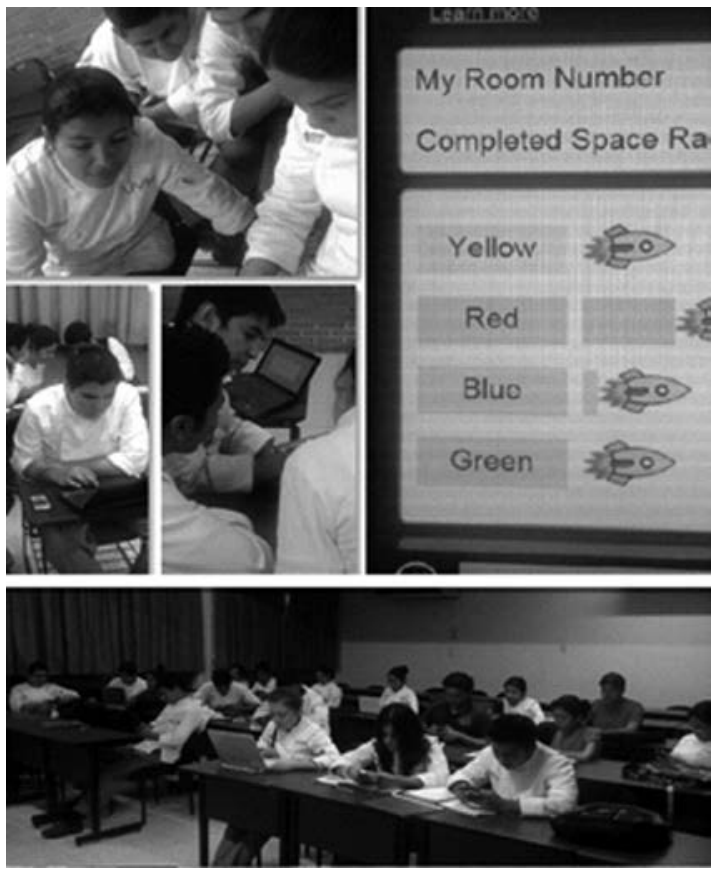

Figure 3. Students Working During Class Activities

Use of tools for practicality and convenience. Another routine adopted by students was taking photos of the notes on the board instead of copying everything into their notebooks. This way of taking notes saved time that could now be devoted to instruction, drilling, and production. Similarly, it became a common practice to ask the teacher-researchers to upload, on Edmodo, the information that had been projected in class, such as PowerPoint and Prezi presentations. For instance, Figure 4 shows that a student uploaded the photo she had taken of the whiteboard in class to share it with all her classmates.

There were plenty of positive consequences for the teacher-researchers as well. For example, the amount of time taken not only to elaborate and grade quizzes, but also to calculate the numeric value of those quizzes as part of the grading criteria declined noticeably. Similarly, providing feedback became simpler and faster, mainly for activities carried out using Edmodo. The students also preferred to take exams on Edmodo rather than on paper, since they had the opportunity to self-evaluate and obtain feedback immediately, which they liked and demonstrated in several conversations among themselves and with the teachers, for 


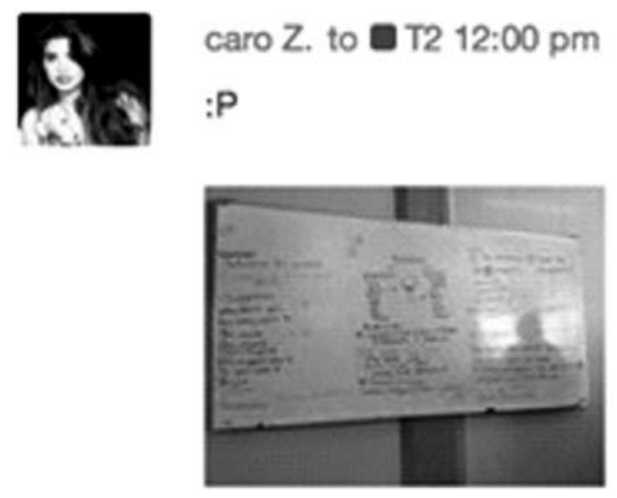

\section{() Dec 4, 2012 - Q Reply · : (-)}

Figure 4. Photo of the Whiteboard Taken by a Student

instance, in the following statement taken from an informal dialog in class: "Teacher, this is better than paper quizzes. I don't have to wait for my results" (translated from Spanish).

\section{Students' Learning and Usage of the Target Language (English) Through Personal Portable Devices}

Use of monolingual dictionaries. It is worth mentioning that we consider the most remarkable change that took place in the students' behavior was the fact that students in Group B started using the monolingual dictionary tools on their own. This particular practice has two important implications:

- They now understand it is possible to obtain the meaning of a word by using the cognates and familiar words found in its definition.

- The need for a Spanish equivalent of unknown words decreased. This represents an important feat when taking into account the fact that the students in Group B were mostly true beginners whose level of confidence depended on Spanish translation.

Figure 5 illustrates how students used the dictionaries (downloaded on their cell phones, tablets, or laptops) to convey the meanings of some words, either individually on their own devices or collaboratively by projecting them on the board. 


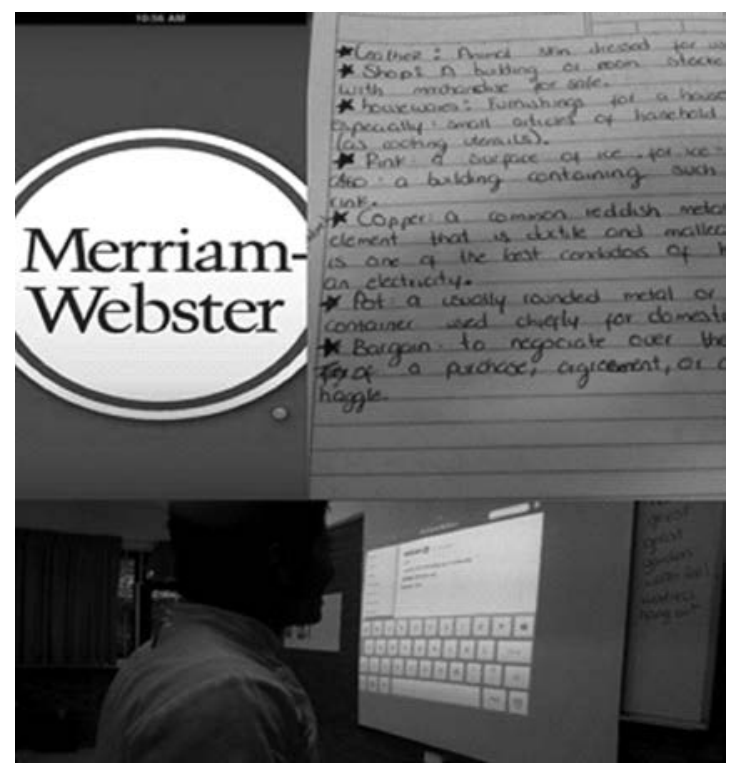

Figure 5. Use of the Dictionary by Students

Use of English to communicate among themselves and work collaboratively. By the end of the implementation process, some of the students in both groups were so used to commenting on each other's contributions on Edmodo that they had started posting messages in English (according to their level) for the rest of the group without the teacher requesting them to do so, as shown in Figure 6.

As has been shown, there were several positive findings regarding the incorporation of cell phones, tablets, and laptops as learning tools in the English classes; however, some

\section{Angel I. to Touchstone 1}

hello everyone I hope you spend a nice weekend, good luck with your exams

2 minutes ago | Reply | Share | Tag *

Figure 6. Message From a Student 
students did not find it motivating enough and continued to be frequently absent from classes. Despite this issue, we consider that the intervention and findings derived from the action research have illustrated the vast number of possibilities to promote a more meaningful learning of a foreign language. We now proceed to the closure of this research report.

\section{Conclusions}

The inclusion of technology in the language classroom is the eventual and logical result of continuous technological advances. Such advances have impacted electronic devices as well as telecommunications, especially now that Internet connection is becoming not only faster, but also more accessible. These developments have led to a significant increase in the worldwide sales of personal portable devices such as cellphones, laptops, and tablets, making them appear as omnipresent in certain contexts.

As we explained in the introductory section, in economically advantaged sectors such as private schools, as the one we work for, teachers are conflicted with the implications of dealing with students who seem more interested in texting and surfing the Internet for fun than in paying attention to lectures and learning. Once we had identified this issue, we set the objectives of this action research and its corresponding educational intervention: to implement an innovative possible solution and investigate its impact on students' learning and using the target language (English) in class.

In other words, we developed and implemented activities related to each English course syllabus, which included the use of personal portable devices (cellphones, tablets, and laptops) as learning tools in class. Thus, we were able to investigate the impact such an implementation had on students' learning and using English in class. From the data gathered and the outcomes we arrived at, we accomplished answering the research questions we had established: The ways personal portable devices could be used efficiently and constructively while doing innovative class activities in accordance with the English language program for the course, and the impact this usage had on students' performance.

The first question has been answered in the section related to the activities that were planned and implemented, since they all included the use of applications such as Edmodo, the Merriam-Webster (monolingual) on-line dictionary, and Socrative, which the students downloaded on their cellphones, tablets (iPads), and/or laptops.

As regards the second question, such activities, according to our observations, helped students become aware of and participate in a culture of the constructive use of personal portable devices. Furthermore, this practice was accomplished while contributing to the students' learning and use of the English language according to the level of the course. We 
believe one of the main factors that contributed to the success of this intervention was the learners' interest, knowledge, and skills in the areas of devices, applications, websites, and social media.

Despite some students' continued absence from classes, or they attended but kept using their portable devices only for fun, most students seemed enthusiastic to participate in the activities implemented. Their attitude towards portable devices became more constructive and they showed an interest in using, on their own, the tools and applications provided; this made us think that the intervention fostered autonomy. Even though this behavior was not perceived in the group totally, as we have already said, the general results were encouraging. Through their participation and work (messages and assignments) on the applications, we observed that students were able to practice and improve their English language use through the use of the portable devices they seem unable to live without: their own laptops, tablets, and cellphones.

Based on students' reactions, it can be inferred that the English teaching community, in general, could benefit from the implementation of this educational intervention proposal. For the teachers, for instance, there was a reduction in the amount of time it took us to prepare materials for their classes thanks to the features of several of the tools used, Edmodo in particular.

However satisfying, the implementation process presented one main constraint: Wi-Fi connection instability. Counting with either the institution's support in terms of classroom mobility, or an appropriate connection system would have guaranteed steady Internet accessibility, and therefore, a more successful implementation. In addition, monitoring what students were doing when using their cellphones was still difficult; however, they seemed more focused on their class tasks.

The number of tools that can be applied in the education field increases every day. Therefore, many other activities, (collaborative) tools, and applications (podcasts, discussion boards, wikis, video and voice recordings, social media, webconferencing, etc.) to fit the needs and interests of a given language class could be developed and researched about. Even within the context where this action research project took place, there are still many windows of opportunity to eventually reach the totality of the student community at UVM.

Teachers interested in implementing these innovative tools (resources) should bear in mind a series of aspects. Firstly, observation is key to determining if students are skillful and interested in personal portable device usage and whether they have or are able to acquire at least one of these devices, which is one of the main requirements to reach the goals of the present project. Secondly, it is important to verify that the applications and activities selected run properly on different devices before implementing them. Lastly, Wi-Fi connectivity should be accessible and dependable. Taking these into consideration and based on the findings of this action research, we suggest that language teachers can indeed take advantage of personal portable devices to enhance language learning and use in class. 


\section{References}

Ally, M. (Ed.). (2009). Mobile learning: Transforming the delivery of education and training. Edmonton, CA: AU Press.

Barraza, A. (2005). Una conceptualización comprehensiva de la innovación educativa [A comprehensive conceptualization of educational innovation]. Innovación Educativa, 5(28), 19-31.

Barraza, A. (2006). Innovación didáctica en educación superior: Un estudio de caso Didactic innovation at higher education: A case study]. Revista Electrónica Diálogos Educativos, 12, 2-15.

Brooks-Young, S. J. (2010). Teaching with the tools kids really use: Learning with web and mobile technologies. Thousand Oaks, CA: Sage Publications.

Burns, A. (2010). Doing action research in English language teaching: A guide for practitioners. New York, NY: Routledge.

Chamot, A. U., Barnhardt, S., \& Dirstine, S. (1998). Conducting action research in the foreign language classroom. Paper presented at the Northeast Conference, New York, 1998. Retrieved from http:// www.studymode.com/essays/Conducting-Action-Research-In-The-Foreign-832950.html

Goundar, S. (2011). What is the potential impact of using mobile devices in education? Proceedings of SIG GlobDev Fourth Annual Workshop. Shanghai, China.

Hannan, A., \& Silver, H. (2000). Innovating in higher education: Teaching, learning and institutional cultures. Buckingham, UK: Society for Research into Higher Education and Open University Press.

Hopkins, D. (1989). Investigación en el aula: guía del profesor [Classroom research: Teacher's guide]. Barcelona, ES: PPU.

Jordán Padrón, M., Pachón González, L., Blanco Pereira, M. E., \& Achiong Alemañy, M. (2011). Elementos a tener en cuenta para realizar un diseño de intervención educativa [Elements to take into account when designing an educative intervention]. Revista Médica Electrónica, 33(4). Retrieved from http://www.revmatanzas.sld.cu/revista\%20medica/ano\%202011/vol4\%202011/ tema17. htm

Kemmis, S., \& Mc'Taggart, R. (Eds.). (1988). The action research planner (3 ${ }^{\text {rd }}$ ed.). Geelong, AU: Deaking University Press.

Lauricella, S., \& Kay, R. (2010). Assessing laptop use in higher education classrooms: The laptop efectiveness scale (LES). Australasian Journal of Educational Technology, 26(2), 151-163.

Lincoln, Y. S., \& Guba, E. G. (1985). Naturalistic inquiry. Thousand Oaks, CA: Sage Publications.

Maykut, P., \& Morehouse, R. (1994). Beginning qualitative research: A philosophic and practical guide. London, UK: Routledge Falmer.

McCoy, B. (2013). Digital distractions in the classroom: Student classroom use of digital devices for non-class related purposes. Faculty Publications, College of Journalism \& Mass Communications, Paper 71. Retrieved from http://digitalcommons.unl.edu/journalismfacpub/71

Naismith, L., Lonsdale, P., Vavoula, G., \& Sharples, M. (2004). Literature review in mobile technologies and learning. Bristol, UK: NESTA Futurelab.

Negrete, T. (2010). La intervención educativa: un campo emergente en México [The educational intervention: An emerging field in Mexico]. Revista de Educación y Desarrollo, 13, 35-43. 
Patton, M. Q. (2002). Qualitative research and evaluation methods (3rd ed.). Thousand Oaks, CA: Sage Publications.

Richards, J. C. (2006). Communicative language teaching today. Retrieved from http:// www.professorjackrichards.com/wp-content/uploads/communicative-language-teaching-t oday-v2.pdf

Robson, C. (2002). Real world research (2 $2^{\text {nd }}$ ed.). Cornwall, UK: Blackwell Publishing.

Rogers, E. M. (1995). Diffusion of innovations (4th ed.). New York, NY: The Free Press.

Sikes, P. J. (1992). Imposed change and the experienced teacher. In M. Fullan \& A. Hargreaves (Eds.), Teacher development and educational change (pp. 36-55), London, UK: The Falmer Press.

Stake, R. (1998). Investigación con estudio de casos [Research through case studies]. Madrid, ES: Ediciones Morata.

State of New South Wales, Department of Education and Communities. (2012). Use of tablet technology in the classroom. Sydney, AU: NSW Curriculum and Learning Innovation Centre.

Suárez Pazos, M. (2002). Algunas reflexiones sobre la investigación-acción colaboradora en la educación [Some reflections on collaborative action research in education]. Revista Electrónica de Enseñanza de las Ciencias, 1(1), 40-56.

Trebbi, T. (2003). Curriculum development and learner autonomy in the foreign language classroom: Constraints and possibilities. In D. Little, J. Ridley, \& E. Ushioda (Eds.), Learner autonomy in the foreign language classroom: Teacher, learner, curriculum, and assessment (pp. 166-184). Dublin, IE: Authentik.

UNESCO. (2012). Mobile learning in Latin America. Paris, FR: United Nations Educational, Scientific, and Cultural Organization.

Valk, J-H., Rashid, A. T., \& Elder, L. (2010). Using mobile phones to improve educational outcomes: An analysis of evidence from Asia. The International Review of Research in Open and Distance Learning, 11(1).

Winter, R. (1989). Learning from experience: Principles and practice in action-research. London, UK: The Falmer Press

\section{The Authors}

Luz Edith Herrera Díaz is a professor-researcher at the Language Center in Universidad Veracruzana (Mexico). She is currently a teacher and the coordinator of the MA TEFL program in Veracruz. She holds a PhD in Language Studies (Kent University, UK).

María de los Milagros Cruz Ramos is a teacher at the Language Center in Universidad Veracruzana and at Universidad del Valle de México, and she works as an e-tutor for the British Council. She holds an MA in TEFL.

Mario Alberto Sandoval Sánchez is a teacher at the Language Center in Universidad Veracruzana and at Universidad del Valle de México, and he works as an e-tutor for the British Council. He holds an MA in TEFL. 